\title{
EFEKTIVITAS KEGIATAN LESSON STUDY DALAM MERANCANG PEMBELAJARAN PADA MATA KULIAH GELOMBANG DAN OPTIK
}

\author{
Rahma Hi. Manrulu ${ }^{1}$, Dian Novita Sari ${ }^{2}$ \\ ${ }^{1}$ Universitas Cokroaminoto Palopo, E-mail: rahma_manrulu@yahoo.com \\ ${ }^{2}$ Program Studi Pendidikan Fisika IAIN Raden Intan Lampung, E-mail: ns.dian11@yahoo.com
}

Diterima: 13 Agustus 2015 Disetujui: 11 Oktober 2015. Dipublikasikan: Oktober 2015

\begin{abstract}
Lesson study has been conducted as a strategy to improve the processes and outcomes of learning, this activity implemented in a collaborative and sustained by a group of lecturer (lecturer models and observers). The main objectives of lesson study activities namely to gain a better understanding of how students learn and lecturers teach, designing the learning that is easily understood by students in each of the learning process and build a pedagogical knowledge, where a lecturer able to gain knowledge from other lecturer. This activity is conducted for four stages during one semester and conducted in stages. Each stage consists of planning (plan), observation (do) and reflection (see). Lesson this lesson study is expected to provide lessons and learning experinces of students in general and, in particular, the lecturer models and able to build cooperative contextual learning. From a series of stages that have been done can be concluded that the need for cooperation in designing an effective learning, maximum and sustainable.
\end{abstract}

\begin{abstract}
Abstrak: Telah dilakukan kegiatan lesson study yang merupakan strategi untuk meningkatkan proses dan hasil pembelajaran yang dilaksanakan secara kolaboratif dan berkelanjutan oleh sekelompok dosen (dosen model dan dosen observer). Tujuan utama kegiatan lesson study yaitu memperoleh pemahaman yang lebih baik tentang bagaimana mahasiswa belajar dan dosen mengajar, merancang pembelajaran yang mudah dipahami oleh mahasiswa dalam setiap proses pembelajaran serta membangun sebuah pengetahuan pedagogis, dimana seorang dosen mampu menimba pengetahuan dari dosen lain. Kegiatan dilakukan selama empat siklus selama satu semester yang dilakukan secara bertahap. Setiap tahapan terdiri dari perencanaan (plan), observasi (do) dan refleksi (see). Pembelajaran ini diharapakan mampu membelajarkan mahasiswa pada umumnya dan dosen model pada khususnya dan mampu membangun pembelajaran kontekstual yang kooperatif. Dari serangkaian siklus yang dilakukan dapat simpulkan bahwa perlu kerjasama dalam merancang sebuah pembelajaran yang efektif, maksimal dan berkelanjutan.
\end{abstract}

Kata Kunci: do, lesson study, plan, see

\section{PENDAHULUAN}

Selama produktivitas masih ada maka selama itu pula pendidikan akan terus ada yang akan linear dengan keberadaan masalah-masalah dalam pendidikan untuk menciptakan pembelajaran yang berkualitas dan anak didik yang handal. Manusia membutuhkan pendidikan untuk membuat hidupnya lebih berkualitas dan tenaga pendidik berkewajiban memenuhi kebutuhan anak didik. Namun kewajiban yang dilaksanakan tenaga pendidik selalu menemui masalah-masalah. Sebagian besar pemerhati pendidikan terus membahas masalah ini dan terus mencari solusi dalam menyelesaikan masalah tersebut. Salah satu program yang banyak diperbincangkan saat ini adalah lesson study. Lesson study bagai bunga yang sedang mekar dan dilirik semua pemerhati pendidikan. Lesson study dianggap sebagai inovasi program pendidikan dalam menyelesaikan 
maslaah yaitu menciptakan pembelajaran yang berkualitas. Hal yang paling mendasar dalam kegiatan lesson study adalah kolaboratif dan berkelanjutan untuk bersama-sama mencerdaskan peserta didiknya. Harapan ideal yang ingin dicapai dalam kegiatan lesson study ini adalah membangun masyarakat belajar, sesuai dengan prinsip belajar sepanjang hayat (life long learning).

Leesson study bukanlah suatu strategi atau metode dalam pembelajaran, tetapi merupakan salah satu upaya pembinaan untuk meningkatkan proses pembelajaran yang dilakukan oleh sekelompok guru atau dosen secara kolaboratif dan berkesinambungan, dalam merencanakan, melaksanakan, mengobservasi dan melaporkan hasil pembelajaran. Lesson study merupakan langkah kongkrit untuk membentuk komunitas belajar (learning society).

Membuat sebuah bahan ajar adalah hal mudah bagi seorang tenaga pendidik, namun membuat sebuah bahan ajar yang berkualitas, berkesinambungan dan mampu diterima oleh mahasiswa dengan mudah adalah hal tersulit yang dirasakan bagi setiap tenaga pendidik. Setiap tenaga pengajar akan menemukan kesulitan yang berbeda dalam pelaksanaan pembelajaran di dalam kelas. Olehnya itu perlu kerjasama dalam kelompok dosen untuk merancang pembelajaran yang efektif serta menyelesaikan masalah-masalah individu tenaga pengajar dalam penyelesaian kolektif. Salah satu upaya yang dapat dilakukan adalah melalui kegiatan lesson study. Kegiatan ini dianggap mampu untuk menyelesaikan masalah-masalah pendidikan yang dihadapi oleh masing-masing tenaga pengajar, oleh karena itulah dirancang kegiatan tersebut.

Adapun masalah yang ditemukan dari siklus pembelajaran ini adalah sebagai berikut:

1. Bagaimana merancang model pembelajaran yang mudah dipahami mahasiswa pada mata kuliah gelombang dan optik?

2. Bagaimana aplikasi model pembelajaran yang maksimal melalui lesson study?

Bahasan dan tinjauan pada penelitian ini dibatasi pada proses pembelajaran selama empat (4) silklus proses pengajaran selama satu (1) semester.

Rancangan pemecahan masalah pada tulisan ini adalah merancang model, perangkat dan materi pembelajaran yang tepat pada setiap pengajaran, sehingga masalah-masalah yang dihadapai dalam pembelajaran dapat diminimalisir demi tercapainya pembelajaran kontekstual yang sebagaimana mestinya.

\section{LANDASAN TEORI}

Lesson Study diartikan sebagai suatu strategi pembinaan profesi pendidik berbasis kelas melalui pengkajian pembelajaran secara kolaboratif yang dilakukan secara terus menerus berdasarkan prinsi-prinsip kolegalitas dan mutuallearning untuk membangun komunitas belajar.

Menurut Supriatna (2014), Lesson Study diartikan sebagai penelitian pembelajaran (research lesson) atau study pembelajaran. Aktivitas yang dilakukan dalam Lesson Study adalah mengkaji semua aspek pembelajaran dengan harapan kita dapat 
membelajarakan siswa secara optimal, dalam hal ini Lesson Study dapat pula diartikan belajar dari pembelajaran. Melalui kegiatan Lesson Study kita dapat meningkatkan kemampuan diri sebagai guru profesional dalam memenuhi hak anak didik belajar serta meningkatkan kualitas anak didik.

Terdapat tiga konsep dalam pembelajaran, yaitu:

1. Pembelajaran individual (individual learning)

2. Pembelajaran Pembelajaran kompetitiv (competitive learning)

3. Pembelajaran kelompok (Group learning).

Seperti telah dikemukakan sebelumnya bahwa model pembelajaran hanyalah salah satu aspek yang dibahas dalam kegiatan lesson study. Semua hal yang termasuk dalam pembelajaran dibahas dalam kegiatan lesson study. Dalam kegiatan perencanaan (plan), pelaksanaan pembelajaran dan observasi (do), serta pada kegiatan refleksi (see) masalah-masalah pembelajaran dibahas dengan tujuan agar siswa dapat mendapatkan pembelajaran secara baik dan optimal .

Usaha yang kita lakukan dalam kegiatan lesson study adalah memenuhi hak anak belajar. Pembelajaran yang diterima anak adalah pembelajaran yang memenuhi kebutuhan perkembangan anak dalam hal ilmunya dan hatinya. Pembelajaran yang diterima anak harus seimbang antara ilmu dan hatinya, dengan harapan anak berkembang menjadi anak yang cerdas dan berhati mulia.

Slamet Mulyana (2007), menjelaskan bahwa lesson study sebagai salah satu model pembinaan profesi pendidik melalui pengkajian pembelajaran secara kolaboratif dan berkelanjutan berlandaskan pada prinsipprinsip kolegalitas dan mutual learning untuk membangun komunitas belajar.

Bill Cerbin \& Bryan Kopp mengemukakan bahwa lesson study memiliki 4 (empat) tujuan utama, yaitu untuk:

1. Membangun pemahaman yang lebih baik tentang bagaimana siswa belajar dan guru/dosen mengajar

2. Memperoleh hasil-hasil tertentu yang bisa dimanfaatkan oleh para guru/dosen lainnya diluar peserta lesson study

3. Meningkatkan pembelajaran secara sistematis melalui inquiri kolaboratif

4. Membangun sebuah pengetahuan pedagogis, dimana seorang guru/dosen dapat menimbah pengetahuan dari guru/dosen lainnya.

Dalam tulisnnya yang lain, Catherine Lewis (2004), mengemukakan pula tentang ciri-ciri esensial dari lesson study yang diperolehnya berdasarkan hasil observasi terhadap beberapa sekolah yang ada di Jepang yaitu:

1. Tujuan bersama untuk jangka panjang. Lesson study didahului adanya kesempatan dari para guru/dosen tentang tujuan bersama yang ingin ditinggalkan dalam kurun waktu jangka panjang dengan cakupan tujuan yang lebih luas, misalnya tentang: pengembangan kemampuan akademik siswa/mahasiswa, pengembangan kemampuan individual siswa/mahasiswa, pemenuhan kebutuhan belajar siswa/mahasiswa, 
pengembangan pembelajaran yang menyenangkan, mengembangkan kerajinan siswa dalam belajar dan sebagainya.

2. Materi pelajaran yang penting. Lesson study memfokuskan pada materi atau bahan pelajaran yang dianggap penting dan menjadi titik lemah dalam pembelajaran siswa serta sangat sulit untuk dipelajari siswa.

3. Study tentang siswa secara cermat. Fokus yang paling utama dalam lesson study adalah pengembangan dan pembelajaran yang dilakukan siswa, misalnya apakah siswa meninjukkan minat dan motivasinya dalam belajar, bagaimana siswa bekerja dalam kelompok kecil, bagaimana siswa melakukan tugastugas yang diberikan guru serta halhal lainnya yang berkaitan dengan aktifitas, partisipasi, serta kondisi yang setiap siswa dalam mengikuti proses pembelajaran. Dengan demikian, pusat perhatian tidak lagi hanya tertuju pada bagaimana cara guru dalam mengajarkan sebagai lazimnya dalam sebuah suoervisi kelas yang dilaksanakan oleh kepala sekolah atau pengawasan sekolah.

4. Observasi pembelajaran secara langsung. Observasi langsung boleh dikatakan merupakan jantungnya lesson study. Untuk menilai kegiatan pengembangan dan pembelajaran yang dilaksanakan siswa tidak cukup dilakukan hanya dengan cara melihat dari Rencana Pelaksanaan Pembelajaran (lesson plan) atau hanya melihat dari tayangan video, namun juga harus mengamati proses pembelajaran secara langsung. Dengan melakukan pengamatan langsung, data yang diperoleh tentang proses pembelajaran akan jauh lebih akurat dan utuh, bahkan sampai halhal yang detail sekalipun dapat digali. Penggunaan videotape atau rekaman bisa saja digunakan hanya sebatas pelengkap, dan bukan sebagai pengganti.

Lesson Study (LS) merupakan pembinaan profesi pendidik melalui pengkajian pembelajaran secara kolaboratif dan berkelanjutan berlandaskan prinsip-prinsip kolegalitas dan mutual learning untuk membangun learning community. Lesson study menyediakan suatu proses untuk berkolaborasi dan merancang lesson (pembelajaran) dan mengevaluasi kesuksesan strategis. Strategi mengajar yang telah diterapkan sebagai upaya meningkatkan proses dan perolehan belajar mahasiswa. Dosen bekerja sama untuk merencanakan, mengajar, dan mengamati suatu pembelajaran yang dikembangkannya secara kooperatif. Tujuan Utama Lesson Study:

1. Meningkatkan pengetahuan tentang materi ajar

2. Meningkatkan pengetahuan tentang pembelajaran

3. Meningkatkan kemampuan mengobservasi aktivitas belajar, meningkatkan hubungan kolegalitas

4. Meningkatkan hubungan antara pelaksanaan pembelajaran sehari-hari dengan tujuan jangka panjang yang harus dicapai

5. Meningkatkan motivasi belajar, baik guru maupun siswa untuk selalu berkembang 
6. Meningkatkan kualitas rencana pembelajaran.

Lesson study atau kaji pembelajaran adalah suatu pendekatan peningkatan pembelajaran yang awal mulanya berasal dari Jepang. Lesson study menyediakan suatu proses untuk berkolaborasi dan merancang lesson (pembelajaran) dan mengevaluasi kesuksesan strategis. Strategi mengajar yang telah diterapkan sebagai upaya meningkatkan proses dan perolehan belajar Mahasiswa. Proses Lesson study tersebut, dosen bekerja sama untuk merencanakan, mengajar, dan mengamati suatu pembelajaran yang dikembangkannya secara kooperatif. Sementara itu, seorang dosen mengimplementasikan pembelajaran dalam kelas, yang lain mengamati, dan mencatat pertanyaan dan pemahaman siswa. Penggunaan proses Lesson Study dengan program pengembangan yang profesional tersebut merupakan wahana untuk mengembalikan dosen kepada budaya mengajar yang proporsional.

Berdasarkan observasi langsung yang dilakukan oleh Chaterine Lewis pada hasil wawancara sejumlah guru mengemukakan keuntungan para guru untuk:

1. Memikirkan secara lebih teliti lagi tentang tujuan, materi tertentu yang akan dibelajarkan kepada siswa

2. Memikirkan secara mendalam tentang tujuan-tujuan pembelajaran untuk kepentingan masa depan siswa, misalnya tentang arti penting sebuah persahabatan, pengembangan perspektif dan cara berfikir siswa, serta kegandrungan siswa terhadap ilmu pengetahuan
3. Mengkaji tentang hal-hal terbaik yang dapat digunakan dalam pembelajaran melalui belajar dari para guru lain (peserta atau partisipan lesson study)

4. Belajar tentang isi atau materi pelajaran dari guru lain sehingga dapat menambah pengetahuan temantang apa yang harus diberikan kepada siswa

5. Mengembangkan keahlian dalam mengajar, baik pada saat merencanakan pembelajaran maupun selama berlangsungnya kegiatan pembelajaran

6. Membangun kemampuan melalui pembelajaran kolegial, dalam arti para guru bisa saling belajar tentang apa-apa yang dirasakan masih kurang, baik tentang pengetahuan maupun keterampilannya dalam membelajarkan siswa

7. Mengembangkan "The eyes to see students", dalam arti dengan dihadirkannya para pengamat (observer), pengamatan tentang perilaku belajar siswa bisa semakin detail dan jelas.

Tujuan dari pelaksanaan kegiatan ini adalah sebagai berikut:

1. Mampu berkolaborasi merancang pembelajaran baik dalam metode maupun materi yang tepat pada setiap pengajaran dalam kolega dosen guna membentuk kompetensi pada anak didik.

2. Manfaat lesson study dalam pembelajaran Gelombang dan Optik.

\section{METODE PENELITIAN}

\section{Jenis Kegiatan}

Kegiatan ini bernama lesson study, kegiatan lesson study merupakan strategi 
pembelajaran untuk meningkatkan kualitas anak didik dan menciptakan guru/dosen profesional. Kegiatan ini dilakukan sebanyak empat siklus selama satu semester. Kegiatan ini dilakukan selama dua semester dan setiap siklus terdiri atas perencanaan (plan), observasi (do) dan refleksi (do). Kelas yang dijadikan sampel pada kegiatan lesson study ini adalah kelas Program Studi Fisika semester V untuk Mata Kuliah Gelombang dan Optik. Mata Kuliah ini terdiri dari 3 (tiga) SKS dan dilaksanakan sebanyak 16 kali tatap muka di dalam kelas.

\section{Waktu dan Tempat Kegiatan}

a. Siklus I

Siklus I terdiri atas perencanaan (plan), observasi (do) dan refleksi (see). Plan kegiatan pada siklus I dilaksanakan pada Hari Senin, Tanggal 20 Oktober 2014 di ruang Fakultas Sains. Do dilaksanakan pada Hari Rabu, Tanggal 22 Oktober 2014 di ruang perkuliahan G6. Selanjutnya see dilaksanakan setelah pelaksanaan pembelajaran di dalam kelas yaitu pada Hari Rabu, Tanggal 22 Oktober 2014 di ruang Program Studi Fisika.

\section{b. Siklus II}

Tahap perencanaan (plan) pada siklus kedua dilaksanankan pada Hari Selasa, Tanggal 11 November 2014 di di ruang Fakultas Sains. Observasi kemudian dilakukan pada Hari Rabu, Tanggal 12 November 2014 di ruang perkuliahan G6 dan dilanjutkan dengan refleksi dihari yang sama di ruang Fakultas Sains. c. Siklus III

Siklus III dimulai dengan tahapan perencanaan pada Hari Kamis, 27 November 2014 di ruang Fakultas Sains. Tahapan observasi dilaksanakan pada Hari Jumat, 28 November 2014 di ruang perkuliahan G6. Pada hari yang sama selanjutnya dilaksanakan refleksi di ruang Program Studi Fisika.

\section{d. Siklus IV}

Siklus ke IV merupakan siklus terakhir dalam pelaksanaan Lesson Study pada semester kedua pelaksanaan kegiatan tersebut. Serangkaian kegiatan mulai dari plan, do dan see dilakukan pada hari yang sama yaitu Hari Rabu, Tanggal 03 Desember 2014. Perencanaan (plan) dilakukan di ruang Program Studi Fisika FSAINS. Tahap observasi (do) dilaksanakan di ruang perkuliahan G6. Selanjutnya tahap refleksi pada siklus IV ini dilaksanakan di ruang Program Studi Fisika.

\section{HASIL DAN PEMBAHASAN}

\section{Siklus I}

a. Perencanaan (Plan)

Sebelum memulai kegiatan di dalam kelas, dosen model bersama para dosen observer bersama-sama terlebih dahulu merancang metode pembelajaran yang akan dilakukan di dalam kelas serta materi yang akan diajarkan. Tahap perencanaan dilakukan pada Hari Senin, Tanggal 20 Oktober 2014 di ruang Fakultas Sains. Kegiatan ini diharapkan mampu menggambarkan situasi yang akan dialami oleh mahasiswa dan dosen sehingga diupayakan mahasiswa mampu menerima dan memahami materi dengan mudah. 
Kegiatan ini dilakukan untuk merancang rencana pembelajaran yang akan dilakukan nantinya pada kegiatan pembelajaran di dalam kelas. Plan pertama membahas pengaturan kelompok dalam kelas dan materi yang akan dibahas oleh setiap kelompok. Sebelum pelaksanaan plan bersama sekelompok dosen, rencana pembelajaran di dalam kelas adalah mahasiswa diarahkan untuk memahami materi secara individu. Namun saat pelaksanaan plan bersama sekelompok dosen, diarahkan untuk melakukan diskusi kelompok dalam membahas materi. Pembelajaran ini dibagi menjadi 3 (tiga) kelompok yang masing-masing kelompok terdiri dari 5 orang. Setiap kelompok diarahkan untuk memahami materi dan setiap individu diarahkan untuk membuat soal beserta jawabannya masing-masing 2 (dua) nomor. Soal ini akan digunakan pada permainan yang akan diadakan pada akhir pertemuan sebelum penguatan materi.

b. Observasi (Do)

Observasi (do) dilaksanakan pada Hari Rabu, Tanggal 22 Oktober 2014 di ruang perkuliahan G6. Materi berjudul "Gelombang dan sifat-sifatnya". Dihadiri oleh 2 (dua) orang dosen observer dan seorang kameramen. Secara keseluruhan pelaksanaan pembelajaran dilakukan sesuai dengan perencanaan yang telah dibuat, namun terkendala pada alokasi waktu diskusi.

Mahasiswa dibagi menjadi 3 (tiga) kelompok dan masing-masing terdiri dari 5 (lima) orang. Setiap kelompok diarahkan untuk memahami materi melalui diskusi kelompok. Lanjutan dari kegiatan diskusi kelompok adalah permainan yang dilakukan antara kelompok, kegiatan ini dijadikan sebagai evaluasi bagi dosen. Melalui kegiatan terebut, dosen meminta mahasiswa untuk bertanya kepada kelompok lain. Mahasiwa yang tidak mampu menjawab pertanyaan dinyatakan gugur dalam permainan. Kelompok dengan jumlah anggota terbanyak yang gugur akan mendapat nilai yang rendah dan nilai ini merupakan nilai untuk semua anggota kelompok, karena pada saat permainan kelompok berlangsung mahasiswa harus mampu menjawab secara individu dalam berkelompok. Pada akhir pembelajaran, dosen melakukan penguatan materi.

c. Refleksi (See)

Refleksi (see) dilaksanakan setelah pelaksanaan pembelajaran di dalam kelas yaitu pada Hari Rabu, Tanggal 22 Oktober 2014 di ruang Program Studi Fisika. Kegiatan ini membahas kembali proses pembelajaran yang dilakukan di dalam kelas beserta kekurangan pembelajaran tersebut. Berbagai refleksi yang dilakukan pada kegiatan ini diantaranya alokasi waktu dan tidak adanya Lembar Kerja Mahasiswa (LKM). Refleksi ini akan dijadikan bahan perbaikan untuk siklus selanjutnya.

\section{Siklus II}

a. Perencanaan (Plan)

Perencanaan (plan) pada siklus II dilaksanakan pada Hari Selasa, Tanggal 11 November 2014 di ruang Fakultas Sains. Perencanaan siklus II lebih menekankan pada pembahasan materi yang akan diajarkan pada tahap observasi. Tim dosen observer mengevaluasi seluruh materi mulai dari apersepsi sampai evaluasi akhir. 
Kolaborasi perencanaan bersama kelompok dosen observer merombak seluruh perencanaan yang dibuat oleh dosen model, materi yang ditawarkan dosen model sebagian dihilangkan dengan menyesuaikan dengan durasi waktu pembelajaran. Pada perencanaan ini dosen model kebingungan menerapkan diskusi kelompok, karena sebagian besar materi merupakan persamaan matematis. Namun kebingungan tersebut terjawabkan melalui tahapan perencanaan yang dilakukan bersama sekelompok dosen. Hal lain yang dibahas pada tahap perencanaan siklus II adalah alokasi waktu, menampilkan video dengan durasi singkat, games sebagai sarana evaluasi akhir serta Lembar Kerja Mahasiswa (LKM). Inilah keuntungan dari pelaksanaan kegiatan lesson study, persiapan pembelajaran yang akan dilakukan di dalam kelas bisa lebih baik dan sempurna serta rencana pembelajaran lebih baik karena dikerjakan secara bersama-sama.

\section{b. Observasi (Do)}

Observasi kemudian dilakukan pada Hari Rabu, Tanggal 12 November 2014 di ruang perkuliahan G6 pukul 08.1512.00 WITA dengan materi "Gerak Harmonik Sederhana (GHS)". Secara keseluruhan pelaksanaan pembelajaran yang dilakukan sesuai dengan perencanaan yang telah dilakukan sehari sebelum pelaksanaan pembelajaran. Pembelajaran mampu terpantau oleh dosen observer dengan mudah karena jumlah mahasiswa terbilang sedikit. Pada awal pembelajaran diberikan apersepsi, apersepsi tersebut diharapkan mampu mengantar tujuan pembelajaran sehingga dapat tercapai hingga akhir pembelajaran. Pembelajaran selanjutnya dilanjutkan oleh dosen model dalam menyampaikan materi dalam bentuk slide power point, dan dilanjutkan dengan menampilkan video pembelajaran yang berdurasi 8,3 menit. Selanjutnya dibagikan LKM untuk menjawab pertanyaan yang diberikan. Pertanyaan tersebut merupakan akumulasi dari apersepsi, proses pembelajaran dan video yang ditampilkan. Selanjutya diakhir pertemuan diberikan evaluasi akhir dengan cara dosen model bertanya langsung pada mahasiswa.

\section{c. Refleksi (See) \\ Pada hari yang sama dilakukan} refleksi untuk mengavaluasi kegiatan pembelajaran dalam kelas yang tidak sesuai dengan perencanaan yang telah dilakukan sebelumnya. Kegiatan tersebut dilaksanakan di ruang Fakultas Sains. Kegiatan tidak lagi membahas alokasi waktu pada setiap tahapan pembelajaran seperti pada siklus I, karena alokasi waktu untuk setiap tahap telah sesuai dengan perencanaan yang dilakukan, namun karena keterlambatan masuk dalam ruangan, tahapan games tidak bisa dilakukan pada akhir pembelajaran. Hal mendasar yang dibahas pada refleksi siklus II adalah materi yang disampaikan yang mungkin belum mampu tertangkap oleh mahasiswa secara keseluruhan. Dosen observer mengevaluasi hal-hal yang dilakukan oleh dosen model dan yang semestinya harus dilakukan dosen model dalam memahamkan mahasiswa. Hal ini menjadi keuntungan terbesar bagi dosen model terutama dalam hal 
memaksimalkan media yang ada agar tujuan pembelajaran dapat tercapai sesuai harapan.

\section{Siklus III}

a. Perencanaan (Plan)

Siklus III dimulai dengan tahapan perencanaan pada Hari Kamis, 27 November 2014 di ruang Fakultas Sains. Diskusi perencanaan pembelajaran di dalam kelas bersama dosen observer menghasilkan model pembelajaran yang berbeda dengan perencanaan dosen model secara individu. Rencana awal yang dilakukan oleh dosen model adalah melakukan apersepsi dan memahamkan materi pada mahasiswa melalui diskusi kelompok, hal ini dimaksudkan agar mahasiswa bisa lebih aktif, selanjutnya penguatan materi oleh dosen melalui animasi-animasi bayangan serta games pada akhir pembelajaran. Namun setelah dilakukan diskusi bersama teman-teman dosen, beberapa bagian dirubah diantaranya dosen menjelaskan tentang "Sinar-sinar istimewa pada cermin dan lensa" serta mahasiswa diarahkan untuk menggambar banyangan pada cermin dan lensa di dalam LKM. Perubahan ini dianggap mampu mengefektifkan waktu dalam memahamkan mahasiswa. Hal ini menjada salah satu point keuntungan dosen dalam sebuah kegiatan Lesson Study, yaitu waktu lebih efisien dan pembelajaran semakin menarik. Hal tersebut tidak terlepas dari peran serta seluruh dosen dalam kelompok diskusi.

b. Observasi (Do)

Tahap do atau tahap pelaksanaan pembelajaran pada siklus III dilaksanakan pada Hari Jumat, 28 November 2014 di ruang perkuliahan G6, dimana kegiatan pembelajaran dimulai dengan dosen model membuka pelajaran. Materi yang diajarkan pada siklus III berjudul "Sinar Istimewa dan Pembentukan Bayangan pada Cermin dan Lensa".

Pembelajaran dimulai Pukul 13.00 WITA. Pada pertemuan sebelumnya, mahasiswa diarahkan untuk merancang alat percobaan bayangan cermin dan lensa sebagai bahan aplikasi dari pembelajaran tersebut. Pembelajaran ini dimaksudkan mampu menjelaskan teori alat yang akan dibuat oleh mahasiswa. Pembelajaran dimulai dengan memberikan apersepsi contoh-contoh benda cermin dan lensa dalam kehidupan sehari-hari, selanjutnya dosen model menyajian materi selama 50 menit sebagai materi inti. Tahapan ketiga dilakukan pembelajaran kolaboratif dalam diskusi kelompok terhadap lanjutan materi yaitu menggambarkan sifar-sifat banyangan pada cermin dan lensa. Mahasiswa dibagi menjadi 4 (empat) kelompok dan masing-masing kelompok mendiskusikan topik yang berbeda.

Hal yang tidak dapat terlaksana pada pembelajaran siklus III di dalam kelas adalah animasi-animasi bayangan yang merupakan penguatan dalam pembelajaran tersebut serta games pada akhir pertemuan sebagai bahan evaluasi. Namun untuk menggunakan waktu yang masih tersedia pada bagian akhir dari pembelajaran siklus III, mahasiswa diminta untuk menjelaskan prosedur kerja dan rancangan alat percobaan yang akan dibuat. 


\section{c. Refleksi (See)}

Tahapan observasi pada siklus III dilaksanakan pada hari yang sama yaitu Hari Jumat, 28 November 2014 di ruang Program Studi Fisika, setelah pembelajaran di dalam kelas terlaksana. Beberapa refleksi yang diberikan oleh dosen observer dalam observasinya yaitu diantaranya mahasiswa kurang memahami kronologi atau langkahlangkah penggambaran bayangan cermin dan lensa melalui sinar-sinar istimewa serta kegiatan-kegiatan yang tidak dibahas pada tahap perencanaan namun dilakukan pada tahap observasi.

\section{Siklus IV}

a. Perencanaan (Plan)

Siklus IV adalah siklus terakhir pada pelaksanaan lesson study pada tahun ini. kegiatan mulai dari plan, do dan see dilakukan pada hari yang sama yaitu Hari Rabu, Tanggal 03 Desember 2014 pukul 06.30 WITA. Perencanaan (plan) dilakukan di ruang Program Studi Fisika FSAINS.

Kegiatan pada perencanaan siklus IV, dosen model bersama-sama dosen observer merancang pembelajaran yang berjudul "Refraksi dan Dispersi pada Prisma”. Pada perencanaan siklus IV, dosen model telah merancang pembelajaran yang akan didiskusikan bersama dosen lainnya. Hasil diskusi, materi yang diajukan oleh dosen model banyak dihilangkan. Materi dianggap terlalu meluas dan akan tidak sesuai dengan alokasi waktu yang ada. Materi yang dihilangkan diganti dengan soalsoal dengan durasi pengerjaan singkat. Soal-soal tersebut merupakan penerapan materi yang dipecahkan secara berkelompok. Pembuatan soal-soal yang disajikan tidak terlepas dari kerja sama sekelompok dosen diskusi pada siklus IV.

\section{b. Observasi (Do)}

Tahap pelaksanaan siklus IV dilaksanakan pada hari yang sama yaitu Hari Hari Rabu, Tanggal 03 Desember 2014 pukul 08.00 WITA di ruang perkuliahan G6. Secara keseluruhan tahapan pembelajaran di dalam kelas merupakan skenario pada tahap perencanaan.

Pembelajaran dimulai dengan apersepsi tentang pelangi selanjutnya diarahkan kepada mahasiswa untuk mengetahui alasan susunan warna pelangi (merah, jingga, kuning, hijau, biru, nila dan ungu). Selanjutnya dosen menyajikan materi dalam bentuk slide power point selama 70 menit. Aplikasi dari penyejian materi adalah mahasiswa diarahkan untuk menjawab soal secara berkelompok. Mahasiswa dibagi menjadi 4 (empat) kelompok dan masing-masing kelompok diberi soal dengan permasalahan yang berbeda. Selanjutnya mahasiswa yang ditunjuk oleh dosen diarahkan untuk mengerjakan di papan tulis. Tujuannya adalah semua mahasiswa mengetahui penyelesaian soal dengan permasalahan yang berbeda.

\section{c. Refleksi (See)}

Refleksi (see) pada siklus terakhir dilakukan pada hari yang sama dengan pelaksanaan perencanaan (plan) dan observasi (do) di kelas yaitu Hari Rabu, Tanggal 03 Desember 2014 pukul 16.00 WITA di ruang Program Studi Fisika FSAINS. Pembelajaran siklus IV dianggap efektif dengan asumsi tujuan 
pembelajaran mampu terpaparkan melalui proses pembelajaran serta mahasiswa mampu memahami materi dengan cepat, namun refleksi kekurangan dalam pembelajaran siklus IV adalah dossen model lupa menghubungkan antara apersepsi dengan materi inti pada proses pembelajaran hingga akhir.

\section{SIMPULAN DAN SARAN}

\section{Simpulan}

Dari serangkaian kegiatan yang telah dilakukan selama empat siklus mulai dari perencanaan, observasi dan refleksi, maka dapat ditarik kesimpulan bahwa:

1. Masing-masing individu dosen mempunyai ide yang berbeda terhadap metode dan penyampaian materi dalam membentuk kompetensi anak didik. Olehnya itu kolaborasi dalam kelompok diskusi antar dosen sangat mendukung dalam merancang sebuah pembelajaran.

2. Lesson study merupakan salah satu inovasi pembelajaran bagi dosen untuk merancang sebuah pembelajaran, dalam lesson study dosen diharapkan mampu membangun sebuah pengetahuan pedagogis, dimana seorang dosen akan belajar dari dosen lain. Dalam artian keberadaan kelompok diskusi antar dosen adalah penyempurna bagi pembelajaran seorang dosen. Hal ini tergambar dari pembelajaran Gelombang dan Optik, dalam pembelajaran tersebut kolaborasi antar dosen sangat membantu dalam memahamkan mahasiswa.

\section{Saran}

Demi peningkatan pembelajaran maka perlu dilakukan kelompokkelompok diskusi yang berkelanjutan dalam merancang sebuah model dan materi pembelajaran yang efektif untuk mahasiswa. Langkah kongkrit dalam diskusi kelompok antar dosen adalah kegiatan lesson study.

\section{DAFTAR PUSTAKA}

Bill Cerbin \& Bryan Kopp. A Brief Inroduction to College Lesson Study. Lesson Study Project. Online:

http://www.uwlax.edu/sotl/lsp/ind ex2.htm

Catherine Lewis. (2004). Does Lesson Study Have a Future in the United States?. Online: sowionline.de/journal/20041/lesson_lewis.htm

Slamet Mulyana. (2007). Lesson Study (Makalah). Kuningan: LPMPJawa Barat.

Supriatna, Asep. (2014). Etika dan Profesionalisme Pendidik untuk Pendidikan Karakter dalam Implementasi Kurikulum 2013. Disajikan pada Seminar Nasional dan Prosiding pada Tanggal 5 Mei 2014. 